\title{
Current Experimental Studies of Gene Therapy in Parkinson's Disease
}

\author{
Jing-ya Lin ${ }^{1}$, Cheng-long Xie ${ }^{2}$, Su-fang Zhang ${ }^{1}$, Weien Yuan ${ }^{3 *}$ and Zhen-Guo Liu ${ }^{1 *}$ \\ ${ }^{1}$ Department of Neurology, Xinhua Hospital Affiliated to the Medical School of Shanghai JiaoTong University, Shanghai, \\ China, ${ }^{2}$ Department of Neurology, The first Affiliated Hospital of Wenzhou Medical University, Wenzhou Medical University, \\ Wenzhou, China, ${ }^{3}$ School of Pharmacy, Shanghai JiaoTong University, Shanghai, China
}

OPEN ACCESS

Edited by:

Oliver von Bohlen und Halbach

Universitätsmedizin Greifswald,

Germany

Reviewed by:

Rongqiao He,

Institute of Biophysics, Chinese

Academy of Sciences (CAS), China

Lingyong $\mathrm{Li}$,

University of Texas MD Anderson

Cancer Center, USA

*Correspondence:

Zhen-Guo Liu

zhenguoliu2004@aliyun.com

Weien Yuan

yuanweien@126.com

Received: 31 October 2016 Accepted: 13 April 2017 Published: 03 May 2017

Citation:

Lin J-y, Xie C-I, Zhang S-f, Yuan W

and Liu Z-G (2017) Current

Experimental Studies of Gene Therapy

in Parkinson's Disease.

Front. Aging Neurosci. 9:126.

doi: 10.3389/fnagi.2017.00126
Parkinson's disease (PD) was characterized by late-onset, progressive dopamine neuron loss and movement disorders. The progresses of PD affected the neural function and integrity. To date, most researches had largely addressed the dopamine replacement therapies, but the appearance of L-dopa-induced dyskinesia hampered the use of the drug. And the mechanism of PD is so complicated that it's hard to solve the problem by just add drugs. Researchers began to focus on the genetic underpinnings of Parkinson's disease, searching for new method that may affect the neurodegeneration processes in it. In this paper, we reviewed current delivery methods used in gene therapies for PD, we also summarized the primary target of the gene therapy in the treatment of PD, such like neurotrophic factor (for regeneration), the synthesis of neurotransmitter (for prolong the duration of L-dopa), and the potential proteins that might be a target to modulate via gene therapy. Finally, we discussed RNA interference therapies used in Parkinson's disease, it might act as a new class of drug. We mainly focus on the efficiency and tooling features of different gene therapies in the treatment of PD.

Keywords: Parkinson's disease, animal models, gene therapy, RNA interference, neurodegeneration

\section{INTRODUCTION}

\section{Treatment for PD}

With the improvement of the medical care, people enjoyed a longer life span, but it also bring about aging problems. The increasing healthy costs and the prevalence of Parkinson's disease (PD) are becoming more severe in modern society (von Campenhausen et al., 2009). But PD is so complicated that treating PD is to treat a moving target, as the disease progressed, one therapy could not solve all the problems (Simonato et al., 2013; Kakkar and Dahiya, 2015).

Treatment for PD can be classified as 3 different types: pharmacotherapy, functional neurosurgery, transplantation and gene therapy.

\section{Pharmacotherapy for Parkinson's Disease}

Among the treatments mentioned above, pharmacotherapy is the most effective one in the early years of PD (Buttery and Barker, 2014). Pharmacotherapy can be divided into two kinds: dopaminergic and non-dopaminergic way. The useing of dopamine receptor agonists, catechol-O-methyltransferase (COMT) and monoamine oxidase (MAO) inhibitors were classified as dopaminergic treatment for PD (Fang et al., 2015; Sharma et al., 2015). Using of COMT and $\mathrm{MAO}$ inhibitors can reduce the motor fluctuations of patients. The MAO inhibitors prolonged the duration of L-dopa action time (Muellner et al., 2015; Sari and Khalil, 2015). But with the disease advancing and the appearance of L-dopa-induced dyskinesia (LID), these therapies shows their 
limitations (Behari and Singhal, 2011). In order to address the problems, sustained or controlled release drugs are developed to therapy the PD (Ren et al., 2011; Yang et al., 2012a,b; Xie et al., 2014). The non-dopaminergic drug amantadine is a $\mathrm{N}$ methyl-D-aspartate (NMDA) receptor antagonist that have mild symptomatic benefits and can decrease LID in a proportion of patient (Paquette et al., 2012; Rascol et al., 2015), other nondopaminergic drug like antagonist of metabotropic glutamate receptors (mGluRs) is still under animal experiment and clinical trials (Johnson et al., 2009; Pahwa et al., 2015). Functional neurosurgery was used in advanced PD, including deep brain stimulation and lesion (Rowland et al., 2016; Verhagen Metman et al., 2016). Surgical treatment for PD can be achieved by pallidotomy and globus pallidus internus (GPi) deep brain stimulation (DBS) and subthalamotomy and subthalamic nucleus deep brain stimulation (DBS) (Poortvliet et al., 2015; Hamani et al., 2016). The GPi surgery has a direct effect on dyskinesia while the subthalamic nucleus (STN) deep brain stimulation (DBS) has a benefit on reducing the dopaminergic drug dose (Munhoz et al., 2014; Poortvliet et al., 2015).

But PD is far more complicated than commonly appreciated. As the disease progressing, the effectiveness of the drugs declined, it became incapable for patients to control the motor symptoms (Olanow et al., 2009; Bartus et al., 2014). Thus, the nigrostriatalmediated motor impairment still lacked an adequate solution.

\section{DELIVERY METHOD OF GENE THERAPY}

The advantage of gene therapy was that we can deliver a gene as an agent to the specific brain region to alter function and treat PD (Stayte and Vissel, 2014), while avoiding the off-target effects (Allen and Feigin, 2014). Although gene therapy is mainly experimental at present, the promising future makes a lot of researchers seeing it as a new class of drugs for PD. Before we review the gene therapies for $\mathrm{PD}$, we should pay some attention to the delivery method of gene therapy first (Oertel and Schulz, 2016).

While the measures we adopted to fix PD needs a lot of considerations, the measures themselves are limited by a lot of factors, for example, the chose of the delivery vector. Basically, we can divide the delivery method into two types: viral and non-viral mediates ways (Latchman and Coffin, 2001; Muramatsu et al., 2002; Lewis et al., 2014).

\section{Viral Vectors Mediate Delivery Methods}

When we talk about typical virus vector, we indicate adenoassociate virus, retroviruses and adenovirus. Adeno-associate virus (AAV) is the most utilized vector in brain (Mochizuki et al., 2002; Fischer et al., 2016). The recombinant adeno-associate virus vector (rAAV) remains the essence of the wild-type AAV. Different subtype of AAV could enter different host-cells due to its capsid structure (Burger and Nash, 2016). AAV mainly transduces cells of nervous system, neurons, astrocytes and part of the microglia. The AAV will not integrated to host-cells, so it might dilution due to cell division. The sending of the vectors can be divided into stereotaxic injection, ventricular delivery and systematic delivery, which often require special equipment. Production of rAAV is labor intensive (Benskey and Manfredsson, 2016a).

The retroviruses include lentivirus and non-lentivirus (Benskey and Manfredsson, 2016b). They were characteristic for the ability to integrate with the host cells, thus it'll not be dilute while the host-cells dividing (Nasri et al., 2014). Compared with the AAV, The retroviruses can carry more gene fragments, nearly $9 \mathrm{~kb}$. The difference between lentivirus and non-lentivirus is that the later cannot traverse the nuclei membranes, it impact actively dividing cells only, while lentivirus impact both dividing and non-dividing cells. And the retrovirus could transfect almost all kinds of cells in nervous system, the production of them is much more easier than AAV (Kumar and Woon-Khiong, 2011; Kobayashi et al., 2016).

Recombinant adenovirus ( $\mathrm{rAd}$ ) had reduced the cytotoxicity and immunogenicity to an acceptable extent. It could carry about $35 \mathrm{~kb}$ of genetic material. The large capacity has its own merits and drawbacks (Uil et al., 2011), for it'll require a certain mineral amount of genes to keep the optimal packaging efficiency. The rAd still have certain immunogenicity although this will not impact the transgene expression. Furthermore, the production of rAd is time consuming (Suzuki et al., 2011). Table 1a is the sum of virus vector mediates gene therapy.

\section{Non-viral Mediates Delivery Methods}

In contrast to the viral vectors, non-viral mediates delivery methods do not rely upon the evolved capabilities of viruses to insert genetic material. The non-viral vector mediates gene transfection were no longer limited by the capacity of gene material. Non-viral mediates delivery methods including electroporation, microneedles, polyethylenimine (PEI), polymersomes, polyspermine, the use of branched molecules and cationic lipid-mediates delivery (Boado, 2007; De

\begin{tabular}{|c|c|c|c|}
\hline Virus & Capability & Delivery method & Limitation \\
\hline \multirow{3}{*}{$\begin{array}{l}\text { Adeno-associate } \\
\text { Virus }\end{array}$} & $4.7 \sim 5 \mathrm{~kb}$ & Stereotaxic injection & Not integrate to host-cell \\
\hline & & Intravenous injection & Dilution due to cell division \\
\hline & & $\begin{array}{l}\text { Intracerebral } \\
\text { ventricular injection }\end{array}$ & $\begin{array}{l}\text { Labor intensive and } \\
\text { special equipment in need }\end{array}$ \\
\hline \multicolumn{4}{|l|}{ RETROVIRUSES } \\
\hline Lentivirus & $9 \mathrm{~kb}$ & Stereotaxic injection & $\begin{array}{l}\text { Safety concerns: } \\
\text { insertional mutagenesis, } \\
\text { Impact both dividing and } \\
\text { none dividing cell }\end{array}$ \\
\hline \multirow[t]{2}{*}{ Non-lentivirus } & & & $\begin{array}{l}\text { Not traverse the nuclear } \\
\text { membrane }\end{array}$ \\
\hline & & & $\begin{array}{l}\text { Impact actively dividing } \\
\text { cells }\end{array}$ \\
\hline \multirow[t]{3}{*}{ Adenovirus } & $\begin{array}{l}\text { Roughly } \\
35 \mathrm{~kb}\end{array}$ & Stereotaxic injection & $\begin{array}{l}\text { Require a certain minimal } \\
\text { amount of gene }\end{array}$ \\
\hline & & & Acute inflammation \\
\hline & & & $\begin{array}{l}\text { Ad product is time } \\
\text { consuming }\end{array}$ \\
\hline
\end{tabular}


Vry et al., 2010; Duan et al., 2012; Xiang et al., 2012; Ma et al., 2013; Chen et al., 2014, 2016a,b; Ge et al., 2014a,b; Peng et al., 2014; Che et al., 2016; Song et al., 2016).

Electroporation is a physical transfection method. It created temporary pores via electrical pulse in cell membranes through which substances like nucleic acids can pass into cells. Electroporation could almost target all the cells types in vitro, including mammalian cells and bacteria (Ding and Fan, 2016). Electroporation is time saving, labor saving, and cut the cost to a low level. It shows less toxicity and immunogenicity (De Vry et al., 2010; Yang B. et al., 2012; Gee et al., 2015).

Cationic lipid-mediated delivery is more rapid than viral ones. It can pack large gene material. The expression onset of RNA is much faster than that with DNA, for it needn't transit the nuclear membrane. RNA delivery is good at short-term transient gene expression, for its quick onset (Hecker, 2016). Comparing with RNA, DNA is benefit for it's longer duration and higher mean level of expression, although the onset of which is slower than RNA (Bauer et al., 2002).

The branched molecules, such as polyethylenimine (PEI), dendrigraft poly-L-lysine and chitosan are kind of physical power (Corso et al., 2005; Trapani et al., 2011; Peng et al., 2014). Which force the cell to take up the exogenous gene materials they packed. The common advantage of them is less cytotoxicity and high transfection rates, some can deliver from the ventricular which simplify the procedure. Further more, some scientists even use them to accomplish non-invasive imaging for tracking (Batrakova et al., 2007; Liu et al., 2013). Table $\mathbf{1 b}$ is the sum of alternative of viral vector-mediates gene transfection.

\section{GENE THERAPY FOR PARKINSON'S DISEASE}

\section{Gene Therapy for Delivery of Neurotrophic Factors}

Neurotrophic factors, such as glial cell-derived neurotrophic factor (GDNF), neurturin are secreted proteins that play regulatory roles in the development, survival and maintenance of the nervous system (Hegarty et al., 2014). While the neurodegeneration progressing, the progresses in the constructor of viral vectors for gene transfer make gene therapy a realistic form for PD treatment.

\section{Gene Therapy of GDNF}

GDNF has attracted a lot of attention for its neurogenerative and neuroprotective effects. In vitro, it promoted the survival of cultured ventral midbrain dopaminergic neuron (Lin et al., 1993; Clarkson et al., 1997; Eggert et al., 1999). Then followed some studies supporting the positive effect of GDNF expression on nigrostriatal degeneration and related motor symptom in PD model animals (Eslamboli et al., 2003, 2005). Considering that the majority of the less advanced PD patients are still fully responsive to L-dopa therapy, they might not accept the irreversible measure. But very early interference of gene therapy after diagnoses may have benefits on them. Some researchers use mifepristone and AAV-5 vectors that expressing GDNF to establish an intermittent and reversible mode to control the expression of GDNF, in this system, mifepristone was used as a gene switch to induce a transient impact on expression.

TABLE 1B | Alternative of viral vector-mediates gene transfection.

\begin{tabular}{|c|c|c|c|}
\hline Non-virus & Capability & Delivery method & Benefit compare to viral vector-mediates gene transfection \\
\hline \multirow[t]{3}{*}{ Electroporation } & $>10 \mathrm{~kb}$ & - & Do not integrate/time saving/cost low \\
\hline & & & Less toxicity/less immunity \\
\hline & & & Higher efficiency/bigger capacity \\
\hline \multicolumn{4}{|c|}{ CATIONIC LIPID MEDIATES DELIVERY } \\
\hline DNA & Unlimited & & Longer duration \\
\hline \multirow{2}{*}{ RNA } & & & Onset of expression is faster than DNA \\
\hline & & & Preferable in some clinical applications \\
\hline \multicolumn{4}{|c|}{ POLYETHYLENIMINE } \\
\hline & Unlimited & Bone-marrow derived macrophage system & Less cytotoxicity \\
\hline & & & Increased cellular uptake and stability \\
\hline & Unlimited & Ventricular delivery & Cross the BBB by specific receptor mediated transcytosis \\
\hline & & & Targeted nanoparticles could accumulate in brain more efficiently \\
\hline \multicolumn{4}{|c|}{ CHITOSAN WITH GRAFT WITH PEI } \\
\hline & Unlimited & Stereotaxic injection & Improved water solubility \\
\hline & & & Low toxicity \\
\hline & & & High transfection efficiency \\
\hline
\end{tabular}


Animals that were injected with the constitutively expressing GDNF vectors showed a long-term and stable improvement on GDNF level, while the animals that were injected mifepristone to induce short-term expression also showed a robust but shortterm improvement (Kirik et al., 2016). These result shows that the new intermittent, reversible methods also have a significant and stable impact on the gene expression while compared with the traditional irreversible way. For those less advanced PD patient, it means that they will have a more safe and useful choice to prevent neurodegeneration. Some scientists use MPTP-treated rhehus monkeys and aged monkeys with parkinsonian symptom as the model animals, both groups use AAV2-GDNF vector injected the putamen, the result turns out that AAV2-GDNF enhanced the locomotor activities and increased the dopaminergic terminals in the putamen (Eberling and Kells, 2009; Johnston et al., 2009). Although there is lot of benefits in the GDNF gene therapy, significant weight loss induced by nigral GDNF expressing is disturbing. The GDNF therapy needs more understanding and further development at every level. Table $2 \mathbf{a}$ is the sum of gene therapy of GDNF.

\section{AVV-Neurturin}

The gene of neurturin is a member of the GDNF gene family. Neurturin (NTN) can rescue dopaminergic neurons damage (Biju et al., 2013). 12 PD patients receive an injection of AAVNTN and their symptomatic syndrome showed a significant improvement, although the dopaminergic terminal showed no significant increases in PET imagination (Marks et al., 2008). However, in an effort to validate the efficacy in the former trial, researchers launched a randomized, sham surgery-controlled, double-blind clinical trials which include 58 PD patients (Marks et al., 2010). There is no significant improvement observed in the NTN-treated patients until it comes to the 18 months, while with the phase I trial only spent 12 months to meet its endpoint.
The outcome of the phase II trial is modest, but significant. In the postmortem analysis of 2 deceased patients demonstrated NTN expression in putamen rather than substantial nigra, shows that there is still limitations in the retrograde transport of $\mathrm{AVV}$ vector. In the purpose to solve the retrograde transport problem, researchers use a more direct way, they directly target the substantial nigra and injected higher dose to putamen, and provide longer clinical follow-up. The result let them down, the clinical trial only demonstrated the tolerability of treatment with CERE-120, the drug was delivered to both parts of substantia nigra pars compacta and putamen without safety complication in a 2-year follow-up (Bartus et al., 2014), but in the subsequent phase II, it failed to show its efficacy. It didn't meet the primary endpoint they expect (off-state motor UPDRS Scores). The result of NTN-treatment was disappointing.

\section{Gene Therapy for Modulating the Synthesis of Neurotransmitter Adeno-Associated Virus (AAV)-Glutamate Decarboxylase (GAD)}

We all know that in PD, the loss of the dopaminergic neuron can result the imbalance in basal ganglia circuitry, for example, the subthalamic nucleus (STN) will receive less GABAergic input. In activation of neurons in the STN of the MPTP-treated monkey model, animals had shown ameliorated parkinsonian motor symptoms (Wichmann et al., 1994; Guridi et al., 1996). The therapeutic effect is consistent with the notion STN hyperactivity or dysfunction in PD (Bergman et al., 1994). Then some researchers want to validate the therapeutic and neuronal effect of blocking STN, they performed microinjection of local anesthetic lidocaine and muscimol, (lidocaine has the none selectively blocking axonal fibers of passage as well as neurons, while muscimol selectively inhibited the cell body of neuron.), this

TABLE 2A | Gene therapy of GDNF.

\begin{tabular}{|c|c|c|c|}
\hline Model animal & Study duration & Target area & Interference of gene therapy \\
\hline \multirow[t]{3}{*}{ 6-OHDA lesioned rats } & 17 weeks & Striatum & Constitutive GDNF expression AAV vector \\
\hline & & & Mifeprestone induced once \\
\hline & & & Mifeprestone induced twice \\
\hline MPTP-rhesus monkeys monkeys & 12 months & Putamen & AAV2-GDNF vector \\
\hline aged naïve monkeys & 6 months & Putamen substrantial nigra & AAV2-GDNF vector \\
\hline
\end{tabular}

\begin{tabular}{|c|c|c|c|}
\hline \multirow{2}{*}{$\begin{array}{l}\text { Interference of gene } \\
\text { therapy }\end{array}$} & \multicolumn{2}{|c|}{ Restoration of the motor control } & \multirow[t]{2}{*}{ Impact on dopaminergic pathway } \\
\hline & Cylinder test & APO-induced rotation & \\
\hline $\begin{array}{l}\text { Constitutive GDNF } \\
\text { expression AAV vector }\end{array}$ & $\begin{array}{l}\text { From } 20 \text { to } 38 \% \text { right } \\
\text { forepaw use }\end{array}$ & $\begin{array}{l}\text { Stable reduction of the Apo induced } \\
\text { rotation by about } 80 \%\end{array}$ & $\begin{array}{l}\text { DA level almost completely restored than the contralateral } \\
\text { hemisphere }\end{array}$ \\
\hline $\begin{array}{l}\text { Mifepristone induced } \\
\text { once }\end{array}$ & $\begin{array}{l}\text { From } 20 \text { to } 38 \% \text { right forepaw } \\
\text { use, then declined to } 25 \% \text { at } 15 \\
\text { weeks after lesion }\end{array}$ & $\begin{array}{l}\text { A reduction by about } 50 \sim 60 \% \\
\text { which lasts } 5 \text { weeks, and then } \\
\text { increased at } 7 \text { weeks }\end{array}$ & Not significantly increased at the end of the experiment \\
\hline $\begin{array}{l}\text { Mifepristone induced } \\
\text { twice }\end{array}$ & $\begin{array}{l}\text { From } 20 \text { to } 35 \% \text { right } \\
\text { forepaw use }\end{array}$ & $\begin{array}{l}\text { Rotation behavior was stable reduced } \\
\text { over the time course of study }\end{array}$ & $\begin{array}{l}\text { Significant lower than those achieved by constitutive GDNF } \\
\text { expression }\end{array}$ \\
\hline AAV2-GDNF vector & \multicolumn{2}{|c|}{ Enhanced locomotor activity } & Increased density of Dopaminergic terminals in the putamen \\
\hline AAV2-GDNF vector & \multicolumn{2}{|c|}{ An increase of basal locomotor activity } & Small increase of AADC activity \\
\hline
\end{tabular}


study shows that microinjections of pharmacological blocking agent in the STN of PD patients result in a transient antiParkinsonian effect (Levy et al., 2001). Then a gene therapy approach was investigated for increasing GABAergic tone in STN. Some scientists use an AAV vector to transfer the gene of GAD to STN. As the rate-limiting enzyme for the synthesis of GABA, this approach could increase the level of GABA in STN and improve the motor symptoms of PD. In the research of the subsequent open label, safety and tolerability clinical trial, they use viral vectors (AAV-GAD) injected $12 \mathrm{PD}$ patients' unilateral subthalamic. The patients were divided into 3 groups; the main efficacy measure was UPDRS. Significant improvement was seen 3 months after gene therapy and persisted up to 12 months. The conclusion of the trial is that AAV-GAD gene therapy of the subthalamic nucleus is safe and well tolerated by patients with advanced PD (Kaplitt et al., 2007).

\section{Aromatic Amino Acid Decarboxylase (AADC) and Tyrosine Hydroxylase/Aromatic Amino Acid Decarboxylase/Guanosine Triphosphate Cyclohydrolase (AADC-TH-GCH) Gene Therapy}

The beneficial effect of oral administration of L-dopa will soon be complicated by motor symptoms. Olanow et al. find that continuous dopamine stimulation might counter balance these long-term effects of drug (Olanow et al., 2000, 2006a,b). Based on these theories, researchers focused on increasing dopamine level through enhancing the chemical synthesis of dopamine from levodopa. The conversion of levodopa to dopamine needs the enzyme acromatic L-amino acid decarbocylase (AADC) (Christine et al., 2009; Muramatsu et al., 2010). With the PD advancing, activities of AADC diminished, this further limiting dopamine level and resulted a larger need for the dosage of levodopa (Witt and Marks, 2011). The transduction of AADC gene to intrinsic striatal neurons could enhance the synthesis of dopamine and might improve the dopamine level in brain. The continuous existence of DA might reduce the need of levodopa in advancing PD (Allen and Feigin, 2014), and with the reduction of levodopa, the side effect like LIDs might be alleviated. A phase I clinical trial of gene transfer of AAV mediated gene delivery of AADC into putamen of 6 PD patients was launched. using multiple measures, including UPDRS, motor state diaries and PET trace for AADC, 6 months after surgery, the off-state of motor function was improved by $46 \%$ based on UPDRS scores, PET shows a 56\% increase in FMT activities, both effect last 96 weeks (Muramatsu et al., 2010).

The TH/AADC/GCH is a triple gene approach. The production of dopamine needs these 3 genes to exert their function. The TH and GCH catalyze the dietary tyrosine convert to levodopa, AADC turns the levodopa to dopamine, the triple gene vectors just like a molecular machinery for manufacturing dopamine (Azzouz et al., 2002; Jarraya et al., 2009). The trisictronic lenti-vector aims to improve the dopamine level in striatal not only by restoring AADC activity, but also by further increasing endo-levodopa in both dopaminergic and non-dopaminergic neurons (Azzouz et al., 2002; Jarraya et al., 2009). This approach brings the good news that it is safe and tolerable, modest improvement in UPDRS-motors of scores was seen at 6 to 12 month (Oxford biomedica).

Although the DA-synthetic strategies have yield encouraging results, but take the small numbers of samples and the likelihood of placebo effect into consideration, further study was awaited (Christine et al., 2009; Palfi et al., 2014).

\section{Gene Therapy for Modulate Proteins in PD}

As we know, 6-OHDA-lesioned Parkinsonian rats had a multiple protein- and brain region-specific changes. The dysregulation of DA receptors induced by the 6-OHDA lesioning is believed to underlie PD pathology and LID. Ahmed et al had reported that the G-protein-coupled receptor kinases (GRKs) had abnormal expression level and the subcellular distribution in the basal ganglia of the 6-OHDA-lesioned parkinsonian rats, and these changes were not normalized by L-dopa treatment. Furthermore, they found that the up-regulation GRK6 (a subtype of GRKs) is similar in both 6-OHDA-lesioned PD rats and in MPTPmonkeys (Ahmed et al., 2008). It is know that G proteincoupled receptor kinases (GRKs) control desensitization of DA receptors. They set out to use a lentiviral system to increase the availability of GRK6 in the purpose to facilitation of the receptor desensitization, this measure ameliorates dyskinesia and increase duration of the antiparkinsonian action of $\mathrm{L}$ dopa. The lentivirus-mediated overexpression of GRK6 is a promising method to alliviating the motor complications of PD (Ahmed et al., 2010, 2015). Recently, a lot of studies demonstrated that glycogen synthase kinase-3 activities was upregulate while treated with high dosage of L-dopa. It was also reported that in MPTP-treated monkeys, increased activation of GSK-3 $\beta$ was combine with the LID (Morissette et al., 2010). It's believed that GSK-3 $\beta$ was involved in the development of LID. Inhibiting the expression of GSK-3 $\beta$ via RNA interference might also be a possible approach to reduce the motor symptoms.

\section{RNA Interference-Based Therapy: A Promising Class of Drug Therapy for PD}

As a very important and resent part of gene therapy, RNA interference (RNAi) is a very useful experimental tool for diagnosis and therapy in PD. RNAi could almost silence any selected gene, via which, we can conclude the genetic reason of a certain disease (Dykxhoorn and Lieberman, 2005; Waseem, 2006; Jadiya et al., 2015; Chaudhuri et al., 2016). When a long doublestrand RNA (dsRNA) produced by an introduced transgene encounter a cell, an enzyme called dicer cut the long dsRNA into small pieces named siRNAs, and then siRNA induced silencing complex (RISC) picked the complementary sequence to the target gene for silencing, so that no protein is produced (Novina and Sharp, 2004; Konno et al., 2016).

\section{RNA Interference and Gene of SNCA, PINK, and Parkin}

Scientists have done a lot of experiments on RNA interference of SNCA (Nagarajan et al., 2015; Takahashi et al., 2015). In vitro, they use polyethylene glycol-polyethyleneimine as a vector for $\alpha$-synuclein siRNA delivery to PC12 cell. The polyethylene 
TABLE 2B | In vivo and In vitro study of RNA interference therapy for PD.

\begin{tabular}{|c|c|c|c|c|}
\hline Complexes & Model animal & \multicolumn{2}{|c|}{$\begin{array}{l}\text { I Level of SCNA } \\
\text { In brain }\end{array}$} & Restoration of motor \\
\hline \multicolumn{5}{|l|}{ I: In vivo } \\
\hline \multirow{2}{*}{$\begin{array}{l}\text { shSCNA } \\
\text { T1-2 }\end{array}$} & PD model flies & \multicolumn{2}{|c|}{ Decreased } & Motor dysfunction increased \\
\hline & & & & $\begin{array}{l}\text { Depending upon the } \\
\text { reduction of SNCA }\end{array}$ \\
\hline $\begin{array}{l}\text { AAV-mir30- } \\
\text { hSCNA }\end{array}$ & & Decre & ased & $\begin{array}{l}\text { Protect against the forelimb } \\
\text { deficit }\end{array}$ \\
\hline Complexes & \multicolumn{2}{|c|}{ Model cell } & \multicolumn{2}{|c|}{ Level of SNCA } \\
\hline \multicolumn{5}{|l|}{ II: In vitro } \\
\hline \multirow[t]{2}{*}{ siSNCA_T1-2 } & \multirow{2}{*}{\multicolumn{2}{|c|}{$\begin{array}{l}\text { PD patients' } \\
\text { fibroblast }\end{array}$}} & \multicolumn{2}{|c|}{$\begin{array}{l}\text { Decreased endogenous SCNA to an half } \\
\text { level }\end{array}$} \\
\hline & & & \multicolumn{2}{|c|}{$\begin{array}{l}\text { The half level of SCNA is similar to that in } \\
\text { normal }\end{array}$} \\
\hline \multirow[t]{2}{*}{ SiSCNA4 } & \multirow{2}{*}{\multicolumn{2}{|c|}{ SH-SY5Y cell }} & \multicolumn{2}{|c|}{ 7.69-fold reduction of SCNA mRNA } \\
\hline & & & \multicolumn{2}{|c|}{ 2.43-fold reduction of SCNA protein } \\
\hline \multirow[t]{2}{*}{ siSCNA1 } & & & \multicolumn{2}{|c|}{ 1.59-fold reduction of SCNA mRNA } \\
\hline & & & \multicolumn{2}{|c|}{ 1.51-fold reduction of SCNA protein } \\
\hline PEG-PEI/siSCN & PC12 & & \multicolumn{2}{|c|}{ Suppress SCNA mRNA expression } \\
\hline
\end{tabular}

glycol-polyethyleneimine (PEG/PEI) siSNCA complex were well developed and with low cytotoxicity. It shows high transfection efficiency, suppressing the SNCA mRNA expression and preventing cell from death via apoptosis induced by 1methyl-4-phenylpyridine (mpp+) (Liu et al., 2014). In vivo, down-regulations of $\alpha$-synuclein shows a promising future for synucleinopathies in PD. Human SNCA gene silencing with AAV-micro30-hSNCA in rat substantia nigra could have benefits on forelimb behavior and substantia nigra dopaminergic neuron loss, but these positive effects was compromised by the inflammation which was triggered by the co-expression of either silencing vector and the reduced Tyrosin hydrocylaseimmunoreactive expression (Bonin et al., 2004; Khodr et al., 2014). Table $\mathbf{2 b}$ is the sum of In vivo and In vitro study of RNA interference therapy for PD.

Some other researchers use the RNAi technique help to form a specific biomarker to detect sporadic PD. Some researchers even use skin fibroblast from PD patients and the control lines with knock-down of PINK1, to investigate the expression changes of SCNA, they reveal that the expression changes detected from the two lines of cell may have the potential to see as a biomarker that allow physician to diagnosis objective $\mathrm{PD}$ in an non-invasive way

\section{REFERENCES}

Ahmed, M. R., Berthet, A., Bychkov, E., Porras, G., Li, Q., Bioulac, B. H., et al. (2010). Lentiviral overexpression of GRK6 alleviates L-dopa-induced dyskinesia in experimental Parkinson's disease. Sci. Transl. Med. 2:28ra28. doi: $10.1126 /$ scitranslmed.3000664
(Hoepken et al., 2008). Mutations in PINK1 associated with early onset autosomal recessive PD, loss of it also caused CI deficiency (Zhang et al., 2013; Ng et al., 2014; Min et al., 2015). Furthermore, PINK1 together with another PD gene, Parkin, co-regulates the mitochondrial morphology and mitophagy (Ivatt et al., 2014).

\section{CONCLUSION}

In recent years, $\mathrm{PD}$ and levodopa-induced dyskinesia remains to be a hard nut to crack. While L-dopa replacement therapy trapped in a dilemma, gene therapy showed its vigorous vitality in biology research. Gene therapy has made several heartstirring progresses: Maddalena et al. (2013) and Tereshchenko et al. (2014) has develop the irreversible gene therapy into a controllable, and reversible manner via the mifepristone as a gene inducer, it make the gene therapy became useful even in the less advanced PD patient, this method can also promoted to other neurodegenerative disease while treated with gene therapy. Ahemd et al. had use the lentivirus-mediated overexpression of GRK6 to desensization the DA receptors, this approach had get lot of benefits that is unattainable while directly targeting the signaling pathways. But a lot of problems still remain: the gene therapy we discussed above is directly sent the complexes to the target area, how can we avoid the inflammation. In the gene therapy of GDNF, weigh loss is a disturbing thing remained unsolved, and the development of some antibody against the GDNF was observed. With the advancing of the biology, we hope to see more help from RNAi that rescue gene deficit than is observed in diagnosis. However, applications of the RNAi technique in clinical practice still have a long way to go.

\section{AUTHOR CONTRIBUTIONS}

JL, CX, SZ, and ZL participated in its design, searched databases, extracted and assessed studies and helped to draft the manuscript. WY conceived the initial idea and the conceptualization; WY and $\mathrm{ZL}$ revised the manuscript. All authors read and approved the final manuscript.

\section{ACKNOWLEDGMENTS}

The study was supported by the Projects of National Science Foundation of China (No. 81200871, 81400925, and 81471148) and Funds for Interdisciplinary Projects of Medicine and Engineering by Shanghai JiaoTong University (No. YG2013MS52, YG2014QN06 and YG2013MS62).
Ahmed, M. R., Bychkov, E., Gurevich, V. V., Benovic, J. L., and Gurevich, E. V. (2008). Altered expression and subcellular distribution of GRK subtypes in the dopamine-depleted rat basal ganglia is not normalized by l-DOPA treatment. $J$. Neurochem. 104, 1622-1636. doi: 10.1111/j.1471-4159.2007.05104.x

Ahmed, M. R., Bychkov, E., Kook, S., Zurkovsky, L., Dalby, K. N., and Gurevich, E. V. (2015). Overexpression of GRK6 rescues 1-DOPA-induced signaling 
abnormalities in the dopamine-depleted striatum of hemiparkinsonian rats. Exp. Neurol. 266, 42-54. doi: 10.1016/j.expneurol.2015.02.008

Allen, P. J., and Feigin, A. (2014). Gene-based therapies in Parkinson's disease. Neurotherapeutics 11, 60-67. doi: 10.1007/s13311-013-0233-2

Azzouz, M., Martin-Rendon, E., Barber, R. D., Mitrophanous, K. A., Carter, E. E., Rohll, J. B., et al. (2002). Multicistronic lentiviral vector-mediated striatal gene transfer of aromatic L-amino acid decarboxylase, tyrosine hydroxylase, and GTP cyclohydrolase I induces sustained transgene expression, dopamine production, and functional improvement in a rat model of Parkinson's disease. J. Neurosci. 22, 10302-10312.

Bartus, R. T., Weinberg, M. S., and Samulski, R. J. (2014). Parkinson's disease gene therapy: success by design meets failure by efficacy. Mol. Ther. 22, 487-497. doi: $10.1038 / \mathrm{mt} .2013 .28$

Batrakova, E. V., Li, S., Reynolds, A. D., Mosley, R. L., Bronich, T. K., Kabanov, A. V., et al. (2007). A macrophage-nanozyme delivery system for Parkinson's disease. Bioconjug. Chem. 18, 1498-1506. doi: 10.1021/bc700184b

Bauer, M., Meyer, M., Brevig, T., Gasser, T., Widmer, H. R., Zimmer, J., et al. (2002). Lipid-mediated glial cell line-derived neurotrophic factor gene transfer to cultured porcine ventral mesencephalic tissue. Exp. Neurol. 177, 40-49. doi: 10.1006/exnr.2002.7965

Behari, M., and Singhal, K. K. (2011). Cell based therapies in Parkinson's disease. Ann. Neurosci. 18, 76-83. doi: 10.5214/ans.0972.7531.1118209

Benskey, M. J., and Manfredsson, F. P. (2016a). Intraparenchymal stereotaxic delivery of rAAV and special considerations in vector handling. Methods Mol. Biol. 1382, 199-215. doi: 10.1007/978-1-4939-3271-9_14

Benskey, M. J., and Manfredsson, F. P. (2016b). Lentivirus production and purification. Methods Mol. Biol. 1382, 107-114. doi: 10.1007/978-1-49393271-9_8

Bergman, H., Wichmann, T., Karmon, B., and DeLong, M. R. (1994). The primate subthalamic nucleus. II. Neuronal activity in the MPTP model of parkinsonism. J. Neurophysiol. 72, 507-520.

Biju, K. C., Santacruz, R. A., Chen, C., Zhou, Q., Yao, J., Rohrabaugh, S. L., et al. (2013). Bone marrow-derived microglia-based neurturin delivery protects against dopaminergic neurodegeneration in a mouse model of Parkinson's disease. Neurosci. Lett. 535, 24-29. doi: 10.1016/j.neulet.2012.12.034

Boado, R. J. (2007). Blood-brain barrier transport of non-viral gene and RNAi therapeutics. Pharm. Res. 24, 1772-1787. doi: 10.1007/s11095-007-9321-5

Bonin, M., Poths, S., Osaka, H., Wang, Y. L., Wada, K., and Riess, O. (2004). Microarray expression analysis of gad mice implicates involvement of Parkinson's disease associated UCH-L1 in multiple metabolic pathways. Brain Res. Mol. Brain Res. 126, 88-97. doi: 10.1016/j.molbrainres.2004.03.025

Burger, C., and Nash, K. R. (2016). Small-Scale recombinant adeno-associated virus purification. Methods Mol. Biol. 1382, 95-106. doi: 10.1007/9781-4939-3271-9_7

Buttery, P. C., and Barker, R. A. (2014). Treating Parkinson's disease in the 21st century: can stem cell transplantation compete? J. Comp. Neurol. 522, 2802-2816. doi: $10.1002 / \mathrm{cne} .23577$

Chaudhuri, A. D., Choi, D. C., Kabaria, S., Tran, A., and Junn, E. (2016). MicroRNA-7 regulates the function of mitochondrial permeability transition pore by targeting VDAC1 expression. J. Biol. Chem. 291, 6483-6493. doi: 10.1074/jbc.M115.691352

Che, J., Tao, A., Chen, S., Li, X., Zhao, Y., and Yuan, W. (2016). Biological response carrier-mediated anti-angiogenesis shRNA for tumor treatment. Sci Rep. 6:35661. doi: 10.1038/srep35661

Chen, S., Feng, J., Ma, L., Liu, Z., and Yuan, W. (2014). RNA interference (RNAi) technology for anti-Vascular endothelial growth factor (VEGF) treatment. Expert Opin. Drug Deliv. 11, 1471-1480. doi: 10.1517/17425247.2014.926886

Chen, W., Li, H., Liu, Z., and Yuan, W. (2016a). Lipopolyplex for therapeutic gene delivery and its application for the treatment of Parkinson's disease. Front. Aging Neurosci. 8:68. doi: 10.3389/fnagi.2016.00068

Chen, W., Li, H., Shi, D., Liu, Z., and Yuan, W. (2016b). Microneedles as a delivery system for gene therapy. Front. Pharmacol. 7:137. doi: 10.3389/fphar.2016.00137

Christine, C. W., Starr, P. A., Larson, P. S., Eberling, J. L., Jagust, W. J., Hawkins, R. A., et al. (2009). Safety and tolerability of putaminal AADC gene therapy for Parkinson disease. Neurology 73, 1662-1669. doi: 10.1212/WNL.0b013e3181c29356
Clarkson, E. D., Zawada, W. M., and Freed, C. R. (1997). GDNF improves survival and reduces apoptosis in human embryonic dopaminergic neurons in vitro. Cell Tissue Res. 289, 207-210. doi: 10.1007/s004410050867

Corso, T. D., Torres, G., Goulah, C., Roy, I., Gambino, A. S., Nayda, J., et al. (2005). Assessment of viral and non-viral gene transfer into adult rat brains using HSV-1, calcium phosphate and PEI-based methods. Folia Morphol. 64, 130-144.

De Vry, J., Martinez-Martinez, P., Losen, M., Temel, Y., Steckler, T., Steinbusch, H. W., et al. (2010). In vivo electroporation of the central nervous system: a non-viral approach for targeted gene delivery. Prog. Neurobiol. 92, 227-244. doi: 10.1016/j.pneurobio.2010.10.001

Ding, X. F., and Fan, M. (2016). Nonviral gene therapy of the nervous system: electroporation. Methods Mol. Biol. 1382, 297-305. doi: 10.1007/9781-4939-3271-9_22

Duan, S., Ge, X., Lu, N., Wu, F., Yuan, W., and Jin, T., (2012). Synthetic polyspermine imidazole-4, 5-amide as an efficient and cytotoxicity-free gene delivery system. Int. J. Nanomed. 7, 3813-3822. doi: 10.2147/IJN.S33101

Dykxhoorn, D. M., and Lieberman, J. (2005). The silent revolution: RNA interference as basic biology, research tool, and therapeutic. Annu. Rev. Med. 56, 401-423. doi: 10.1146/annurev.med.56.082103.104606

Eberling, J. L., and Kells, A. P. (2009). Functional effects of AAV2-GDNF on the dopaminergic pathway in Parkinsonian rhesus monkeys. Hum. Gene Ther. 8, 511-518. doi: 10.1089/hum.2008.201

Eggert, K., Schlegel, J., Oertel, W., Wurz, C., Krieg, J. C., and Vedder, H. (1999). Glial cell line-derived neurotrophic factor protects dopaminergic neurons from 6-hydroxydopamine toxicity in vitro. Neurosci. Lett. 269, 178-182. doi: 10.1016/S0304-3940(99)00443-7

Eslamboli, A., Cummings, R. M., Ridley, R. M., Baker, H. F., Muzyczka, N., Burger, C., et al. (2003). Recombinant adeno-associated viral vector (rAAV) delivery of GDNF provides protection against 6-OHDA lesion in the common marmoset monkey (Callithrix jacchus). Exp. Neurol. 184, 536-548. doi: 10.1016/j.expneurol.2003.08.007

Eslamboli, A., Georgievska, B., Ridley, R. M., Baker, H. F., Muzyczka, N., Burger, C., et al. (2005). Continuous low-level glial cell line-derived neurotrophic factor delivery using recombinant adeno-associated viral vectors provides neuroprotection and induces behavioral recovery in a primate model of Parkinson's disease. J. Neurosci. 25, 769-777. doi: 10.1523/JNEUROSCI.4421-04.2005

Fang, J. Y., Perez, A., Christine, C. W., Leehey, M., Aminoff, M. J., Boyd, J. T. (2015). Parkinson's disease severity and use of dopaminergic medications. Parkinsonism Relat. Disord. 21, 297-299. doi: 10.1016/j.parkreldis.2014.10.016

Fischer, D. L., Gombash, S. E., Kemp, C. J., Manfredsson, F. P., Polinski, N. K., Duffy, M. F., et al. (2016). Viral Vector-Based Modeling of Neurodegenerative Disorders: Parkinson's disease. Methods Mol. Biol. 1382, 367-382. doi: 10.1007/978-1-4939-3271-9_26

Ge, X., Feng, J., Chen, S., Zhang, C., Ouyang, Y., Liu, Z., et al. (2014a). Biscarbamate cross-linked low molecular weight Polyethylenimine polycation as an efficient intra-cellular delivery cargo for cancer therapy. J. Nanobiotech. 12:13. doi: 10.1186/1477-3155-12-13

Ge, X., Zhang, Q., Cai, Y., Duan, S., Chen, S., Lv, N., et al. (2014b). PEG-PCL-DEX Polymersomes - protamine vector as an efficient gene delivery system by PEG guided self-assembly. Nanomedicine 9, 1193-1207. doi: 10.2217/nnm.13.83

Gee, J. M., Gibbons, M. B., Taheri, M., Palumbos, S., Morris, S. C., Smeal, R. M., et al. (2015). Imaging activity in astrocytes and neurons with genetically encoded calcium indicators following in utero electroporation. Front. Mol. Neurosci. 8:10. doi: 10.3389/fnmol.2015.00010

Guridi, J., Herrero, M. T., Luquin, M. R., Guillen, J., Ruberg, M., Laguna, J., et al. (1996). Subthalamotomy in parkinsonian monkeys. Brain 119(Pt 5), 1717-1727. doi: 10.1093/brain/119.5.1717

Hamani, C., Lozano, A. M., Mazzone, P. A., Moro, E., Hutchison, W., Silburn, P. A., et al. (2016). Pedunculopontine nucleus region deep brain stimulation in Parkinson disease: surgical techniques, side effects, and postoperative imaging. Stereotact. Funct. Neurosurg. 94, 307-319. doi: 10.1159/0004 49011

Hecker, J. G. (2016). Non-Viral, Lipid-Mediated DNA and mRNA gene therapy of the Central Nervous System (CNS): chemical-based transfection. Methods Mol. Biol. 1382, 307-324. doi: 10.1007/978-1-4939-3271-9_23 
Hegarty, S. V., O'Keeffe, G. W., and Sullivan, A. M. (2014). Neurotrophic factors: from neurodevelopmental regulators to novel therapies for Parkinson's disease. Neural Regen. Res. 9, 1708-1711. doi: 10.4103/1673-5374.143410

Hoepken, H. H., Gispert, S., Azizov, M., Klinkenberg, M., Ricciardi, F., Kurz, A., et al. (2008). Parkinson patient fibroblasts show increased alpha-synuclein expression. Exp. Neurol. 212, 307-313. doi: 10.1016/j.expneurol.2008.04.004

Ivatt, R. M., Sanchez-Martinez, A., Godena, V. K., Brown, S., Ziviani, E., and Whitworth, A. J. (2014). Genome-wide RNAi screen identifies the Parkinson disease GWAS risk locus SREBF1 as a regulator of mitophagy. Proc. Natl. Acad. Sci. U.S.A. 111, 8494-8499. doi: 10.1073/pnas.1321207111

Jadiya, P., Fatima, S., Baghel, T., Mir, S. S., and Nazir, A. (2015). A Systematic RNAi screen of neuroprotective genes identifies novel modulators of AlphaSynuclein-Associated Effects in Transgenic Caenorhabditis elegans. Mol. Neurobiol. 53, 6288-6300. doi: 10.1007/s12035-015-9517-3

Jarraya, B., Boulet, S., Ralph, G. S., Jan, C., Bonvento, G., Azzouz, M., et al. (2009). Dopamine gene therapy for Parkinson's disease in a nonhuman primate without associated dyskinesia. Sci. Transl. Med. 1:2ra4. doi: $10.1126 /$ scitranslmed.3000130

Johnson, K. A., Conn, P. J., and Niswender, C. M. (2009). Glutamate receptors as therapeutic targets for Parkinson's disease. CNS Neurol. Disord. Drug Targets 8, 475-491. doi: 10.2174/187152709789824606

Johnston, L. C., Eberling, J., Pivirotto, P., Hadaczek, P., Federoff, H. J., Forsayeth, J. et al. (2009). Clinically relevant effects of convection-enhanced delivery of AAV2-GDNF on the dopaminergic nigrostriatal pathway in aged rhesus monkeys. Hum. Gene Ther. 20, 497-510. doi: 10.1089/hum.2008.137

Kakkar, A. K., and Dahiya, N. (2015). Management of Parkinsons disease: current and future pharmacotherapy. Eur. J. Pharmacol. 750C, 74-81. doi: 10.1016/j.ejphar.2015.01.030

Kaplitt, M. G., Feigin, A., Tang, C., Fitzsimons, H. L., Mattis, P., Lawlor, P. A., et al. (2007). Safety and tolerability of gene therapy with an adeno-associated virus (AAV) borne GAD gene for Parkinson's disease: an open label, phase I trial. Lancet 369, 2097-2105. doi: 10.1016/S0140-6736(07)60982-9

Khodr, C. E., Becerra, A., Han, Y., and Bohn, M. C. (2014). Targeting alpha-synuclein with a microRNA-embedded silencing vector in the rat substantia nigra: positive and negative effects. Brain Res. 1550, 47-60. doi: 10.1016/j.brainres.2014.01.010

Kirik, D., Cederfjall, E., Halliday, G., and Petersen, A. (2016). Gene therapy for Parkinson's disease: disease modification by GDNF family of ligands. Neurobiol. Dis. 97(Pt B), 179-188. doi: 10.1016/j.nbd.2016.09.008

Kobayashi, K., Kato, S., Inoue, K., Takada, M., and Kobayashi, K. (2016). Altering entry site preference of lentiviral vectors into neuronal cells by pseudotyping with envelope glycoproteins. Methods Mol. Biol. 1382, 175-186. doi: 10.1007/978-1-4939-3271-9_12

Konno, T., Siuda, J., and Wszolek, Z. K. (2016). Genetics of Parkinson's disease: a review of SNCA and LRRK2. Wiad. Lek. 69, 328-332.

Kumar, P., and Woon-Khiong, C. (2011). Optimization of lentiviral vectors generation for biomedical and clinical research purposes: contemporary trends in technology development and applications. Curr. Gene Ther. 11, 144-153. doi: $10.2174 / 156652311794940782$

Latchman, D. S., and Coffin, R. S. (2001). Viral vectors for gene therapy in Parkinson's disease. Rev. Neurosci. 12, 69-78. doi: 10.1515/REVNEURO. 2001.12.1.69

Levy, R., Lang, A. E., Dostrovsky, J. O., Pahapill, P., Romas, J., SaintCyr, J., et al. (2001). Lidocaine and muscimol microinjections in subthalamic nucleus reverse Parkinsonian symptoms. Brain 124, 2105-2118. doi: 10.1093/brain/124.10.2105

Lewis, T. B., Glasgow, J. N., Harms, A. S., Standaert, D. G., and Curiel, D. T. (2014). Fiber-modified adenovirus for central nervous system Parkinson's disease gene therapy. Viruses 6, 3293-3310. doi: 10.3390/v6083293

Lin, L. F., Doherty, D. H., Lile, J. D., Bektesh, S., and Collins, F. (1993). GDNF: a glial cell line-derived neurotrophic factor for midbrain dopaminergic neurons. Science 260, 1130-1132. doi: 10.1126/science.8493557

Liu, Y., Guo, Y., An, S., Kuang, Y., He, X., Ma, H., et al. (2013). Targeting caspase- 3 as dual therapeutic benefits by RNAi facilitating brain-targeted nanoparticles in a rat model of Parkinson's disease. PLoS ONE 8:e62905. doi: 10.1371/journal.pone.0062905

Liu, Y. Y., Yang, X. Y., Li, Z., Liu, Z. L., Cheng, D., Wang, Y., et al. (2014). Characterization of polyethylene glycol-polyethyleneimine as a vector for alpha-synuclein siRNA delivery to PC12 cells for Parkinson's disease. CNS Neurosci. Ther. 20, 76-85. doi: 10.1111/cns.12176

Ma, L., Wei, L., Wu, F., Hu, Z., Liu, Z., and Yuan, W. (2013). Advances with microRNAs in Parkinson's disease research. Drug Des. Dev. Ther. 7, 1103-1113. doi: 10.2147/DDDT.S48500

Maddalena, A., Tereshchenko, J., Bahr, M., and Kugler, S. (2013). Adeno-associated virus-mediated, mifepristone-regulated transgene expression in the brain, molecular therapy. Nucl. Acids 2:e106. doi: 10.1038/mtna.2013.35

Marks, W. J. Jr., Bartus, R. T., Siffert, J., Davis, C. S., Lozano, A., Boulis, N., et al. (2010). Gene delivery of AAV2-neurturin for Parkinson's disease: a double-blind, randomised, controlled trial. Lancet Neurol. 9, 1164-1172. doi: 10.1016/s1474-4422(10)70254-4

Marks, W. J. Jr., Ostrem, J. L., Verhagen, L., Starr, P. A., Larson, P. S., Bakay, R. A., et al. (2008). Safety and tolerability of intraputaminal delivery of CERE120 (adeno-associated virus serotype 2-neurturin) to patients with idiopathic Parkinson's disease: an open-label, phase I trial. Lancet Neurol. 7, 400-408. doi: 10.1016/s1474-4422(08)70065-6

Min, B., Kwon, Y. C., Choe, K. M., and Chung, K. C. (2015). PINK1 phosphorylates transglutaminase 2 and blocks its proteasomal degradation. J. Neurosci. Res. 93, 722-735. doi: 10.1002/jnr.23535

Mochizuki, H., Miura, M., Shimada, T., and Mizuno, Y. (2002). Adeno-associated virus-mediated antiapoptotic gene delivery: in vivo gene therapy for neurological disorders. Methods 28, 248-252. doi: 10.1016/S1046-2023(02)00229-3

Morissette, M., Samadi, P., Hadj Tahar, A., Belanger, N., and Di Paolo, T. (2010). Striatal Akt/GSK3 signaling pathway in the development of L-Dopa-induced dyskinesias in MPTP monkeys. Prog. Neuropsychopharmacol. Biol. Psychiatry 34, 446-454. doi: 10.1016/j.pnpbp.2009.12.011

Muellner, J., Gharrad, I., Habert, M. O., Kas, A., Martini, J. B., Cormier-Dequaire, F., et al. (2015). Dopaminergic denervation severity depends on COMT Val158Met polymorphism in Parkinson's disease. Parkinsonism Relat. Disord. 21, 471-476. doi: 10.1016/j.parkreldis.2015.02.009

Munhoz, R. P., Cerasa, A., and Okun, M. S. (2014). Surgical treatment of dyskinesia in Parkinson's disease. Front. Neurol. 5:65. doi: 10.3389/fneur.2014.00065

Muramatsu, S., Fujimoto, K., Kato, S., Mizukami, H., Asari, S., Ikeguchi, K., et al. (2010). A phase I study of aromatic L-amino acid decarboxylase gene therapy for Parkinson's disease. Mol. Ther. 18, 1731-1735. doi: 10.1038/mt. 2010.135

Muramatsu, S., Wang, L., Ikeguchi, K., Fujimoto, K., Nakano, I., and Ozawa, K. (2002). Recombinant adeno-associated viral vectors bring gene therapy for Parkinson's disease closer to reality. J. Neurol. 249(Suppl. 2), II36-II40. doi: $10.1007 / \mathrm{s} 00415-002-1207-1$

Nagarajan, A., Bodhicharla, R., Winter, J., Anbalagan, C., Morgan, K., Searle, M., et al. (2015). D. de-Pomerai, a fluorescence resonance energy transfer assay for monitoring alpha- synclein aggregation in a caenorhabditis elegans model for Parkinson's disease. CNS Neurol. Disord. Drug Targets 14, 1054-1068. doi: $10.2174 / 1871527314666150821110538$

Nasri, M., Karimi, A., and Allahbakhshian Farsani, M. (2014). Production, purification and titration of a lentivirus-based vector for gene delivery purposes. Cytotechnology 66, 1031-1038. doi: 10.1007/s10616-013-9652-5

Ng, A. C., Baird, S. D., and Screaton, R. A. (2014). High-content functional genomic screening to identify novel regulators of the PINK1-Parkin pathway. Methods Enzymol. 547, 1-20. doi: 10.1016/B978-0-12-801415-8.00001-1

Novina, C. D., and Sharp, P. A. (2004). The RNAi revolution. Nature 430, 161-164. doi: $10.1038 / 430161$ a

Oertel, W., and Schulz, J. B. (2016). Current and experimental treatments of Parkinson disease: a guide for neuroscientists. J. Neurochem. 139(Suppl. 1), 325-337. doi: 10.1111/jnc. 13750

Olanow, C. W., Obeso, J. A., and Stocchi, F. (2006a). Drug insight: continuous dopaminergic stimulation in the treatment of Parkinson's disease. Nat. Clin. Pract. Neurol. 2, 382-392. doi: 10.1038/ncpneuro0222

Olanow, C. W., Obeso, J. A., and Stocchi, F. (2006b). Continuous dopaminereceptor treatment of Parkinson's disease: scientific rationale and clinical implications. Lancet Neurol. 5, 677-687. doi: 10.1016/s1474-4422(06) 70521-x

Olanow, C. W., Stern, M. B., and Sethi, K. (2009). The scientific and clinical basis for the treatment of Parkinson disease. Neurology 72, S1-S136. doi: 10.1212/WNL.0b013e3181ald44c 
Olanow, W., Schapira, A. H., and Rascol, O. (2000). Continuous dopaminereceptor stimulation in early Parkinson's disease. Trends Neurosci. 23, S117-S126. doi: 10.1016/S1471-1931(00)00030-6

Pahwa, R., Tanner, C. M., Hauser, R. A., Sethi, K., Isaacson, S., Truong, D., et al. (2015). Amantadine extended release for levodopa-induced dyskinesia in Parkinson's disease (EASED Study). Mov. Disord. 30, 788-795. doi: $10.1002 / \mathrm{mds} .26159$

Palfi, S., Gurruchaga, J. M., Ralph, G. S., Lepetit, H., Lavisse, S., Buttery, P. C., et al. (2014). Long-term safety and tolerability of ProSavin, a lentiviral vector-based gene therapy for Parkinson's disease: a dose escalation, open-label, phase $1 / 2$ trial. Lancet 383, 1138-1146. doi: 10.1016/S0140-6736(13)61939-X

Paquette, M. A., Martinez, A. A., Macheda, T., Meshul, C. K., Johnson, S. W., Berger, S. P., et al. (2012). Anti-dyskinetic mechanisms of amantadine and dextromethorphan in the 6-OHDA rat model of Parkinson's disease: role of NMDA vs. 5-HT1A receptors. Eur. J. Neurosci. 36, 3224-3234. doi: 10.1111/j.1460-9568.2012.08243.x

Peng, Y. S., Lai, P. L., Peng, S., Wu, H. C., Yu, S., Tseng, T. Y., et al. (2014). Glial cell line-derived neurotrophic factor gene delivery via a polyethylene imine grafted chitosan carrier. Int. J. Nanomedicine 9, 3163-3174. doi: 10.2147/IJN.S60465

Poortvliet, P. C., Silburn, P. A., Coyne, T. J., and Chenery, H. J. (2015). Deep brain stimulation for Parkinson disease in Australia: current scientific and clinical status. Int. Med. J. 45, 134-139. doi: 10.1111/imj.12656

Rascol, O., Perez-Lloret, S., and Ferreira, J. J. (2015). New treatments for levodopa-induced motor complications. Mov. Disord. 30, 1451-1460. doi: $10.1002 / \mathrm{mds} .26362$

Ren, T., Yang, X., Wu, N., Cai, Y., Liu, Z., and Yuan, W. (2011). Sustained-release formulation of levodopa methyl ester/benserazide for prolonged suppressing dyskinesia expression in 6-OHDA-leisoned rats. Neurosci. Lett. 502, 117-122. doi: 10.1016/j.neulet.2011.07.042

Rowland, N. C., Kalia, S. K., Kalia, L. V., Larson, P. S., Lim, D. A., and Bankiewicz, K. S. (2016). Merging DBS with viral vector or stem cell implantation: "hybrid" stereotactic surgery as an evolution in the surgical treatment of Parkinson's disease. Mol. Ther. Methods Clin. Dev. 3:15051. doi: 10.1038/mtm. 2015.51

Sari, Y., and Khalil, A. (2015). Monoamine oxidase inhibitors extracted from tobacco smoke as neuroprotective factors for potential treatment of Parkinson's disease. CNS Neurol. Disord. Drug Targets 14, 777-785. doi: 10.2174/1871527314666150325235608

Sharma, S., Singh, S., Sharma, V., Singh, V. P., and Deshmukh, R. (2015). Neurobiology of l-DOPA induced dyskinesia and the novel therapeutic strategies. Biomed. Pharmacother. 70, 283-293. doi: 10.1016/j.biopha. 2015.01.029

Simonato, M., Bennett, J., Boulis, N. M., Castro, M. G., Fink, D. J., Goins, W. F., et al. (2013). Progress in gene therapy for neurological disorders. Nat. Rev. Neurol. 9, 277-291. doi: 10.1038/nrneurol.2013.56

Song, J., Chen, Y., Jiang, S., Yang, K., Li, X., Zhao, X., et al. (2016). Efficient and nontoxic biological response carrier delivering TNF- $\alpha$ shRNA for gene silencing in a murine model of rheumatoid arthritis. Front. Immunol. 7:305. doi: 10.3389/fimmu.2016.00305

Stayte, S., and Vissel, B. (2014). Advances in non-dopaminergic treatments for Parkinson's disease. Front. Neurosci. 8:113. doi: 10.3389/fnins.2014.00113

Suzuki, T., Sasaki, T., Yano, K., Sakurai, F., Kawabata, K., Kondoh, M., et al. (2011). Development of a recombinant adenovirus vector production system free of replication-competent adenovirus by utilizing a packaging size limit of the viral genome. Virus Res. 158, 154-160. doi: 10.1016/j.virusres.2011.03.026

Takahashi, M., Suzuki, M., Fukuoka, M., Fujikake, N., Watanabe, S., Murata, M., et al. (2015). Normalization of overexpressed alpha-synuclein causing Parkinson's disease by a moderate gene silencing with RNA interference. Mol. Ther. Nucleic Acids 4:e241. doi: 10.1038/mtna.2015.14

Tereshchenko, J., Maddalena, A., Bahr, M., and Kugler, S. (2014). Pharmacologically controlled, discontinuous GDNF gene therapy restores motor function in a rat model of Parkinson's disease. Neurobiol. Dis. 65, 35-42. doi: 10.1016/j.nbd.2014.01.009

Trapani, A., De Giglio, E., Cafagna, D., Denora, N., Agrimi, G., Cassano, T., et al. (2011). Characterization and evaluation of chitosan nanoparticles for dopamine brain delivery. Int. J. Pharm. 419, 296-307. doi: 10.1016/j.ijpharm.2011.07.036

Uil, T. G., Vellinga, J., de Vrij, J., van den Hengel, S. K., Rabelink, M. J., Cramer, S. J., et al. (2011). Directed adenovirus evolution using engineered mutator viral polymerases. Nucleic Acids Res. 39:e30. doi: 10.1093/nar/ gkq1258

Verhagen Metman, L., Pal, G., and Slavin, K. (2016). Surgical treatment of Parkinson's disease. Curr. Treat. Options Neurol. 18:49. doi: 10.1007/ s11940-016-0432-3

von Campenhausen, S., Winter, Y., Gasser, J., Seppi, K., Reese, J. P., Pfeiffer K. P., et al. (2009). [Cost of illness and health service patterns in Morbus Parkinson in Austria]. Wien. Klin. Wochenschr. 121, 574-582. doi: 10.1007/ s00508-009-1223-6

Waseem, T. (2006). RNA interference: a potential revolution in disease therapy. J. Coll. Physicians Surg. Pak. 16, 491-492.

Wichmann, T., Bergman, H., and DeLong, M. R. (1994). The primate subthalamic nucleus. III. Changes in motor behavior and neuronal activity in the internal pallidum induced by subthalamic inactivation in the MPTP model of parkinsonism. J. Neurophysiol. 72, 521-530.

Witt, J., and Marks, W. J. Jr., (2011). An update on gene therapy in Parkinson's disease. Curr. Neurol. Neurosci. Rep. 11, 362-370. doi: 10.1007/s11910-011-0197-8

Xiang, S., Su, J., Tong, H., Yang, F., Tong, W., Yuan, W., et al. (2012). Small molecular cross-linked poly(ethylene imine) through biscarbamate linkage, a promising tool to deliver IL-1Ra gene to synoviral cells for arthritis therapy. Biomaterials 33, 6520-6532. doi: 10.1016/j.biomaterials.2012.05.044

Xie, C., Wang, W., Zhang, S., Yuan, M., Che, J., Gan, J., et al. (2014). Levodopa/benserazide microsphere (LBM) prevents Ldopa induced dyskinesia by inactivation of the DR1/PKA/P-tau pathway in 6-OHDA-lesioned Parkinson's rats. Sci. Rep. 4:7506. doi: 10.1186/1477-3155-12-13

Yang, B., Geary, L. B., and Ma, Y. C. (2012). In ovo electroporation in chick midbrain for studying gene function in dopaminergic neuron development. J. Vis. Exp. 3:e4017. doi: 10.3791/4017

Yang, X., Chen, Y., Hong, X., Wu, N., Song, L., Yuan, W., et al. (2012a). Levodopa/benserazide microspheres reduced levodopa-induced dyskinesia by downregulating phosphorylated GluR1 expression in 6-OHDA-lesioned rats. Drug Des. Dev. Ther. 6, 341-347. doi: 10.2147/DDDT.S38008

Yang, X., Zheng, R., Cai, Y., Yuan, W., Liao, M., and Liu, Z. (2012b). Control released levodopa methyl ester/benserazide-loaded nanoparticles ameliorated levodopa-induced dyskinesia in dyskinetic rats. Int. J. Nanomed. 7, 2077-2086. doi: 10.2147/IJN.S30463

Zhang, L., Karsten, P., Hamm, S., Pogson, J. H., Muller-Rischart, A. K., Exner N., et al. (2013). TRArescues PINK1 loss-of-function phenotypes. Hum. Mol. Genet. 22, 2829-2841. doi: 10.1093/hmg/ddt132

Conflict of Interest Statement: The authors declare that the research was conducted in the absence of any commercial or financial relationships that could be construed as a potential conflict of interest.

Copyright (c) 2017 Lin, Xie, Zhang, Yuan and Liu. This is an open-access article distributed under the terms of the Creative Commons Attribution License (CC $B Y)$. The use, distribution or reproduction in other forums is permitted, provided the original author(s) or licensor are credited and that the original publication in this journal is cited, in accordance with accepted academic practice. No use, distribution or reproduction is permitted which does not comply with these terms. 